\title{
Dynamic of Phosphorus Fractions in Typic Quartzipsamment Soil Cropped With Bean
}

\author{
Alessandra Mayumi Tokura Alovisi ${ }^{1}$, Ademar Pereira Serra ${ }^{2}$, Alves Alexandre Alovisi ${ }^{1}$, Luciene Kazue Tokura ${ }^{3}$, \\ Elaine Reis Pinheiro Lourente ${ }^{1}$, Leandro Flávio Carneiro ${ }^{4}$, Marcos Antonio Camacho da Silva ${ }^{5}$, \\ Livia Maria Chamma Davide ${ }^{1}$, Silvia Correa Santos ${ }^{1} \&$ Robervaldo Soares da Silva ${ }^{1}$ \\ ${ }^{1}$ Faculdade de Ciências Agrárias, Universidade Federal da Grande Dourados, Dourados, Mato Grosso do Sul, \\ Brazil \\ ${ }^{2}$ Brazilian Agricultural Research Corporation, Campo Grande, Mato Grosso do Sul, Brazil \\ ${ }^{3}$ Universidade Estadual do Oeste do Paraná, Cascavel, Paraná, Brazil \\ ${ }^{4}$ Universidade Federal de São João del Rei, Sete Lagoas, Minas Gerais, Brazil \\ ${ }^{5}$ Universidade Estadual de Mato Grosso do Sul, Aquidauana, Mato Grosso do Sul, Brazil \\ Correspondence: Alessandra M. Tokura Alovisi, Faculdade de Ciências Agrárias, Universidade Federal da \\ Grande Dourados, Dourados, Mato Grosso do Sul, Brazil. E-mail: alessandraalovisi@ufgd.edu.br
}

Received: May 27, $2018 \quad$ Accepted: July 7, $2018 \quad$ Online Published: August 15, 2018

doi:10.5539/jas.v10n9p493 URL: https://doi.org/10.5539/jas.v10n9p493

\begin{abstract}
Phosphorus is the most limited nutrient in Brazilian soils for plant growth, resulted of low availability and poor $\mathrm{P}$ content in bedrock. The aim of the study was to evaluate the dynamic of P fractions in a sand soil typical Quartzipsamment cropped with common bean under the effects of P and Si-fertilizer rates. The research was carried out in a soil with sand texture and clay mineralogy constituted mainly by kaolinite, classified as Neossolo Quartzarênico Órtico típico (RQo). The greenhouse location was the campus of Universidade Federal de Lavras located in the city of Lavras, state of Minas Gerais, Brazil (approximately $21^{\circ} 13^{\prime} 46.54^{\prime \prime} \mathrm{S}$ and $44^{\circ} 58^{\prime} 26.30^{\prime \prime} \mathrm{W}$, average altitude $932 \mathrm{~m}$ above sea level). The experimental design used was entirely random, arranged in a $4 \times 3$ factorial design, with four repetitions, with amount of 48 experimental units. The treatments included four $P$ rates $\left(0,80,240\right.$ and $\left.410 \mathrm{mg} \mathrm{dm}^{-3}\right)$ and four Si rates $\left(0,240\right.$ and $\left.410 \mathrm{mg} \mathrm{dm}^{-3}\right)$. Phosphorus fractions in soil are little affected by Si-fertilizer rates. P uptakes by bean plants are correlated to the labile and moderately labile fractions. P-fertilizer rates increment majority the stable $\mathrm{P}$ fraction in soil and in lower proportion the labile and moderately labile $\mathrm{P}$ fractions in soil. $\mathrm{Po}-\mathrm{NaHCO}_{3}$ is the only that contributes to bean plant nutrition.
\end{abstract}

Keywords: P and Si-fertilizer, P fractionation, Phaseolus vulgaris

\section{Introduction}

Brazilian soil is composed basically by soil with natural low fertility, and among these soils, great amount are composed by typic quartzipsamment soil, considered as low crop production potential due to intrinsic features: sand granulometry, low nutrient availability and high drainage (Albuquerque, Almeida, Gatiboni, \& Eltz, 2011).

Among the chemical elements, the highest constraints for crop production are imposed by phosphorus $(\mathrm{P})$ limitation. $\mathrm{P}$ adsorption complexity and higher affinity with soil mineral components impact on nutrient availability for plants uptake. $\mathrm{P}$ distribution in soil is present in net crystalline of some soil mineral until more stable fractions as organic matter, which compose the total $\mathrm{P}$ fractions in soil that is constituted of organic and inorganic fractions. These organic and inorganic $\mathrm{P}$ fractions in soil are present under dynamic balance (Alovisi et al., 2016).

$\mathrm{P}$ adsorption is directly correlated with clay content in soil due to capacity of $\mathrm{P}$ adsorption in broken face of silicate clay as well as iron (Fe) and aluminum (Al) oxi-hydroxide. Furthermore, mineralogical composition of soil shows important role in soil $\mathrm{P}$ adsorption, which is justified by the bind energy between $\mathrm{P}$ and each mineralogical soil fraction (Tokura et al., 2011). Kaolinite is the major silicate mineral in expressive amount in soil highly weathering, goethite and hematite area the major $\mathrm{Fe}$ oxide, and gibbsite is considered the only $\mathrm{Al}$ oxide in highly weathering soil (Fontes, Camargo, \& Sposito, 2001). 
Beside the mineralogical composition of the soil, phosphate adsorption is related to the presence of anions competition for the same adsorption site in soil solution (Brait, 2008). Researches related to concentration of silicate in soil solution can promote alteration in the characteristic of phosphate adsorption in soil, resulting in decreasing the intensity of P adsorption turn P more available for plant uptake (Menegale, Castro, \& Mancuso, 2015). Thus, knowledge about ionic interaction and $P$ forms distribution in soil can offer relevant information of $\mathrm{P}$ dynamic in soil and plant, improving the evaluation process of soil availability (Tokura et al., 2011; Alovisi et al., 2016). The knowledge of $P$ dynamic can help in guide soil fertilizer recommendation for crops and the possible silicate affects can contribute for increasing $P$ availability and possible decreasing $P$ fertilizer rates.

$\mathrm{P}$ distribution can be estimated by fractionation method, based on extractors with different extractions. The most used method was proposed by Hedley, Stewart, and Chauhan. (1982), which allows to obtain information about $\mathrm{P}$ availability in short-term and long-term, by means of $\mathrm{P}$ content determination with many degrees of availability using extractor sequencing of lower to higher extraction strength, resulting in removing $\mathrm{P}$ from the more available to the less available form.

The aim of the study was to evaluate the dynamic of P fractions in a sand soil typical Quartzipsamment cropped with common bean under the effects of $\mathrm{P}$ and Si-fertilizer rates.

\section{Materials and methods}

\subsection{Location and Soil Description}

The research was carried out in a soil with sand texture and clay mineralogy constituted mainly by kaolinite, classified according to Santos et al. (2013) as Neossolo Quartzarênico Órtico típico (RQo) [Quartzipsamment (Soil Taxonomy)]. The greenhouse location was the campus of Universidade Federal de Lavras located in the city of Lavras, state of Minas Gerais, Brazil (approximately $21^{\circ} 13^{\prime} 46.54^{\prime \prime}$ S and 44 $58^{\prime} 26.30^{\prime \prime}$ W, average altitude $932 \mathrm{~m}$ above sea level).

\subsection{Soil Properties Evaluations}

The soil was collected in 0-20 cm depth under native vegetation of Brazilian Cerrado biome, located in city of Itutinga, state of Minas Gerais, Brazil. After collection, the soil was air-dried, brokes up and passed through a 5 $\mathrm{mm}$ sieve for the greenhouse experiments. A portion of the samples was passed through a $2 \mathrm{~mm}$ sieve and then subjected to physical, chemical and mineralogical analyses. The physical analysis involved the determination of the granulometric fractions of the air-dried soil (ADS) using the pipette method (Day, 1965).

Chemical analyses included $\mathrm{pH}$, sorption complex, organic $\mathrm{C}$, macronutrients and micronutrients content. Phosphorus (P) availability was measured using Mehlich-1 extractor (Claessen, 1997) and ion-exchange resin (Raij \& Feitosa, 1980). Free Fe oxy-hydroxides from clay fraction were obtained by dissolution with dithionite-citratebicarbonate (Fed) (Mehra \& Jackson, 1960). The less crystalline Fe oxy-hydroxides of the clay fraction was obtained with ammonium oxalate acid (FeO) according to Schwertman, Kodama, and Fisher (1986), and the iron and aluminum oxy-hydroxides by ADS sulphuric attack were determined according to Claessen (1997).

In the free clay, gibbsite and kaolinite contents were quantified using differential thermal analysis. Soluble Si in the soils was determined according to the method proposed by McKeaque and Cline (1963). The results of the physical, chemical and mineralogical characterization of the studied soil before the application of the treatments are presented on Table 1.

\subsection{Experimental Design and Treatments Implementation}

The experimental design used was entirely random, arranged in a $4 \times 3$ factorial, with four repetitions, with amount of 48 experimental units. The treatments included four P rates $\left(0,80,240\right.$ and $\left.410 \mathrm{mg} \mathrm{dm}^{-3}\right)$ and four Si rates $\left(0,240\right.$ and $\left.410 \mathrm{mg} \mathrm{dm}^{-3}\right)$. The P fertilizer rates were defined by the remaining P (Alvarez, Novais, Dias, \& Oliveira, 2000). Vases with a soil capacity of $3 \mathrm{dm}^{3}$ were filled with $2.7 \mathrm{dm}^{3}$ of soil.

The soil samples were then subjected to three sequential incubations for a period of 30 days each under humidity conditions equivalent to $60 \%$ of the total pore volume (TPV) occupied by water (Freire, Ribeiro, Bahia, Lopes, \& Aquino, 1980), which was controlled by daily weighing. The three incubations followed this sequence: 1) incubation after dolomitic limestone application, which was through the micropulverised calcined dolomitic limestone $(35 \% \mathrm{CaO}$ and $14 \% \mathrm{MgO})$ applied to the soils in sufficient quantity to elevate the value of the base saturation to $70 \% ; 2)$ incubation after $\mathrm{Si}$ application, the silicic acid was applied in the form of $\mathrm{H}_{4} \mathrm{SiO}_{4}(60 \%$ $\mathrm{SiO}_{2}$ ) at the rates of 0,110 and $410 \mathrm{mg} \mathrm{dm}^{-3}$ of $\mathrm{Si}$, as defined based on the P rates; and 3) incubation after basic 
fertilization corresponded to the following nutrient contents in the form of salts p.a. in $\mathrm{mg} \mathrm{dm}^{-3}$ of soil: 100 of $\mathrm{N}$; 150 of $\mathrm{K} ; 62$ of S; 0.81 of $\mathrm{B} ; 1.3$ of $\mathrm{Cu} ; 5.0$ of $\mathrm{Zn} ; 3.6$ of Mn; 1.6 of Fe and 0.15 of Mo.

The nutrients were applied in a solution form and mixed into the soil for a higher uniformity. The sources of nutrients were: $\quad \mathrm{K}_{2} \mathrm{SO}_{4} ; \quad\left(\mathrm{NH}_{4}\right)_{2} \mathrm{HPO}_{4} ; \quad \mathrm{NH}_{4} \mathrm{NO}_{3} ; \quad \mathrm{KH}_{2} \mathrm{PO}_{4} ; \quad \mathrm{H}_{3} \mathrm{PO}_{4} ; \quad \mathrm{MnSO}_{4} \cdot 2 \mathrm{H}_{2} \mathrm{O} ; \quad \mathrm{CuSO}_{4} \cdot 5 \mathrm{H}_{2} \mathrm{O}$; $\left(\mathrm{NH}_{4}\right) 6 \mathrm{Mo}_{7} \mathrm{O}_{24} \cdot 4 \mathrm{H}_{2} \mathrm{O} ; \mathrm{ZnSO}_{4} \cdot 7 \mathrm{H}_{2} \mathrm{O} ; \mathrm{FeSO}_{4} \cdot 7 \mathrm{H}_{2} \mathrm{O}$, and $\mathrm{H}_{3} \mathrm{BO}_{3}$. After the incubation period of the soils with the treatments in the greenhouse, soil subsamples of each experimental unit (vases) were collected for the analytical determinations (Table 2).

Planting was done 30 days after the last incubation. Five common bean seeds per vase were sown. After 20 days, the plants were thinned, leaving two plants per vase. The vases were maintained with the humidity at $60 \%$ of the TPV (Freire et al., 1980) through the daily weighing of the vases and the addition of deionized water. The cultivar of the common bean plant used was ESAL 168. Topdressing fertilization with $\mathrm{N}$ and $\mathrm{K}$ were conducted according to the growth of the plants. The treatments received 200 and $170 \mathrm{mg} \mathrm{dm}^{-3}$ of $\mathrm{N}$ and $\mathrm{K}$, respectively, parceled out in seven applications, in addition to the application of $20 \mathrm{mg}$ of sulphur.

Table 1. Chemical, physical and mineralogical soil properties

\begin{tabular}{|c|c|}
\hline Soil properties & Quartzipsamment \\
\hline $\mathrm{pH}_{\mathrm{H} 2 \mathrm{O}}$ & 5.0 \\
\hline $\mathrm{Al}^{+3}\left(\mathrm{cmol}_{\mathrm{c}} \mathrm{dm}^{-3}\right)$ & 0.9 \\
\hline $\mathrm{Ca}^{+2}\left(\mathrm{cmol}_{\mathrm{c}} \mathrm{dm}^{-3}\right)$ & 0.4 \\
\hline $\mathrm{Mg}^{2+}\left(\mathrm{cmol}_{\mathrm{c}} \mathrm{dm}^{-3}\right)$ & 0.1 \\
\hline $\mathrm{K}^{+}\left(\mathrm{mg} \mathrm{dm}^{-3}\right)$ & 23.0 \\
\hline $\mathrm{H}^{+}+\mathrm{Al}^{3+}\left(\mathrm{cmol}_{\mathrm{c}} \mathrm{dm}^{-3}\right)$ & 4.5 \\
\hline Mehlich1-P $\left(\mathrm{mg} \mathrm{dm}^{-3}\right)$ & 6.8 \\
\hline $\operatorname{Resin}-\mathrm{P}\left(\mathrm{mg} \mathrm{dm}{ }^{-3}\right)$ & 5.4 \\
\hline $\mathrm{SB}\left(\mathrm{cmol}_{\mathrm{c}} \mathrm{dm}^{-3}\right)$ & 0.6 \\
\hline Effective CEC $\left(\mathrm{cmol}_{\mathrm{c}} \cdot \mathrm{dm}^{-3}\right)$ & 1.5 \\
\hline $\mathrm{CEC}$ to $\mathrm{pH} 7.0\left(\mathrm{cmol}_{\mathrm{c} .} \mathrm{dm}^{-3}\right)$ & 5.1 \\
\hline BS (\%) & 12.0 \\
\hline m (\%) & 60.0 \\
\hline $\mathrm{OM}\left(\mathrm{dag} \mathrm{kg}^{-1}\right)$ & 1.7 \\
\hline $\mathrm{Si}\left(\mathrm{mg} \mathrm{dm}^{-3}\right)$ & 1.3 \\
\hline $\mathrm{B}\left(\mathrm{mg} \mathrm{dm}^{-3}\right)$ & 0.3 \\
\hline $\mathrm{Cu}\left(\mathrm{mg} \mathrm{dm}{ }^{-3}\right)$ & 1.0 \\
\hline $\mathrm{Fe}\left(\mathrm{mg} \mathrm{dm}^{-3}\right)$ & 60.2 \\
\hline $\operatorname{Mn}\left(\mathrm{mg} \mathrm{dm}^{-3}\right)$ & 6.4 \\
\hline $\mathrm{Zn}\left(\mathrm{mg} \mathrm{dm}^{-3}\right)$ & 0.1 \\
\hline Coarse sand $\left(\mathrm{g} \mathrm{kg}^{-1}\right)$ & 470.0 \\
\hline Thin sand $\left(\mathrm{g} \mathrm{kg}^{-1}\right)$ & 460.0 \\
\hline Silt $\left(\mathrm{g} \mathrm{kg}^{-1}\right)$ & 10.0 \\
\hline Clay $\left(\mathrm{g} \mathrm{kg}^{-1}\right)$ & 60.0 \\
\hline $\mathrm{SiO}_{2}\left(\mathrm{~g} \mathrm{~kg}^{-1}\right)$ & 31.0 \\
\hline $\mathrm{Al}_{2} \mathrm{O}_{3}\left(\mathrm{~g} \mathrm{~kg}^{-1}\right)$ & 36.0 \\
\hline $\mathrm{Fe}_{2} \mathrm{O}_{3}\left(\mathrm{~g} \mathrm{~kg}^{-1}\right)$ & 11.0 \\
\hline $\mathrm{TiO}_{2}\left(\mathrm{~g} \mathrm{~kg}^{-1}\right)$ & 5.0 \\
\hline $\mathrm{P}_{2} \mathrm{O}_{5}\left(\mathrm{~g} \mathrm{~kg}^{-1}\right)$ & 0.0 \\
\hline $\mathrm{Fe}_{\mathrm{d}}\left(\mathrm{g} \mathrm{kg}^{-1}\right)$ & 2.0 \\
\hline $\mathrm{Fe}_{\mathrm{o}}\left(\mathrm{g} \mathrm{kg}^{-1}\right)$ & 0.1 \\
\hline $\mathrm{Ct}\left(\mathrm{g} \mathrm{kg}^{-1}\right)$ & 778.0 \\
\hline $\mathrm{Gb}\left(\mathrm{g} \mathrm{kg}^{-1}\right)$ & 59.0 \\
\hline
\end{tabular}

Note. CEC: Cation Exchange Capacity; total acidity pH $7.0\left(\mathrm{H}^{+}+\mathrm{Al}^{3+}\right)$; Exchangeable $\left(\mathrm{KCl} 1 \mathrm{~mol} \mathrm{~L}{ }^{-1}\right) \mathrm{Ca}^{2+}$, $\mathrm{Mg}^{2+}$ and $\mathrm{Al}^{3+} ; \mathrm{BS}$ : Base Saturation $=(\Sigma$ cations/CEC $) \times 100 ; \mathrm{Ct}$ : kaolinite; Gb: Gibbsite. 


\subsection{Plant Material and Measurement}

The first mature leaves at the tip of the common bean plant branch were collected at the onset of flowering (Malavolta, Vitti, \& Oliveira, 1997) from each vase, and the whole plants were harvested at the physiological maturation of the grains by cutting the plants at ground level. The vegetable matter was dried in a forced-air oven at a temperature between 65 and $70{ }^{\circ} \mathrm{C}$, and ground in Willey-type mill. The total $\mathrm{P}$ content was determined through the mineralisation with nitric-perchloric digestion (Malavolta et al., 1997), and the extracts were measured using colorimetry (Braga \& Defelipo, 1974). The aerial part dry matter (APDM) and grains dry matter (GDM) were determined in the plants harvested at the end of the growth cycle. The P accumulated in the aerial part was calculated by multiplying the APDM value by the content of $\mathrm{P}$ and dividing this value by 1,000 .

\subsection{Phosphorus Fractionation in the Soil}

The phosphorus fractionation in soil was carried before and after the common bean cultivation, the collection of samples were carried out in each experimental units to analytical determinations and for Hedley sequential Po (P organic) and $\mathrm{Pi}\left(\mathrm{P}\right.$ inorganic) fractionations (resin-Pi, $\mathrm{NaHCO}_{3}-\mathrm{Po}, \mathrm{NaHCO}_{3}-\mathrm{Pi}, \mathrm{NaOH} 0.1 \mathrm{M}-\mathrm{Po}, \mathrm{NaOH} 0.1$ $M$-Pi, NaOH 0.5 M-Po, NaOH 0.5 M-Pi, HCl-Pi, and residual-Pi), following methodology of Hedley et al. (1982). The $\mathrm{P}$ forms were determined as follow: labile $\mathrm{P}$ forms (resin- $\mathrm{Pi}, \mathrm{NaHCO}_{3}-\mathrm{Po}$, and $\mathrm{NaHCO}_{3}-\mathrm{Pi}$ ), moderately labile ( $\mathrm{NaOH} 0.1 M-\mathrm{Po}, \mathrm{NaOH} 0.1 M-\mathrm{Pi}, \mathrm{NaOH} 0.5 M-\mathrm{Po}$, and $\mathrm{NaOH} 0.5 M-\mathrm{Pi}$ ), and stable $\mathrm{P}$ fractions (HCl-Pi, and residual-Pi).

Table 2. Soil properties after soil acidity correction, basic fertilizing and treatment applications

\begin{tabular}{|c|c|c|c|c|c|c|c|c|c|c|c|}
\hline Treatments $^{1}$ & $\mathrm{pH}$ & $\mathrm{K}$ & $\mathrm{Ca}$ & $\mathrm{Mg}$ & $\mathrm{Al}$ & $\mathrm{H}+\mathrm{Al}$ & CEC & $\mathrm{m}$ & BS & Resin-P & $\mathrm{Si}$ \\
\hline & & $\mathrm{mg} \mathrm{dm}^{-3}$ & \multicolumn{5}{|c|}{ - } & \multicolumn{2}{|c|}{--------- \% --------- } & \multicolumn{2}{|c|}{------ $\mathrm{mg} \mathrm{dm}^{-3}$----- } \\
\hline $\mathrm{P}_{0} \mathrm{Si}_{0}$ & 5.4 & 119 & 1.9 & 1.1 & 0.2 & 2.4 & 5.7 & 4.7 & 58.1 & 13.9 & 2.63 \\
\hline $\mathrm{P}_{0} \mathrm{Si}_{240}$ & 5.4 & 118 & 2.0 & 1.0 & 0.1 & 2.3 & 5.7 & 4.0 & 59.4 & 13.6 & 6.67 \\
\hline $\mathrm{P}_{0} \mathrm{Si}_{410}$ & 5.3 & 121 & 1.8 & 1.3 & 0.2 & 2.4 & 5.8 & 6.0 & 58.7 & 14.2 & 8.00 \\
\hline $\mathrm{P}_{80} \mathrm{Si}_{0}$ & 5.4 & 117 & 1.8 & 1.2 & 0.2 & 0.4 & 5.7 & 6.0 & 58.1 & 27.5 & 2.63 \\
\hline $\mathrm{P}_{80} \mathrm{Si}_{240}$ & 5.2 & 117 & 1.8 & 1.2 & 0.2 & 0.5 & 5.7 & 6.0 & 56.0 & 27.2 & 6.35 \\
\hline $\mathrm{P}_{80} \mathrm{Si}_{410}$ & 5.3 & 114 & 1.8 & 1.0 & 0.2 & 2.6 & 5.6 & 6.0 & 53.5 & 28.8 & 8.60 \\
\hline $\mathrm{P}_{240} \mathrm{Si}_{0}$ & 5.3 & 112 & 1.7 & 1.2 & 0.2 & 2.7 & 5.8 & 5.0 & 53.2 & 73.4 & 2.84 \\
\hline $\mathrm{P}_{240} \mathrm{Si}_{240}$ & 5.1 & 113 & 1.7 & 1.1 & 0.2 & 2.9 & 6.0 & 6.0 & 51.7 & 73.3 & 6.11 \\
\hline $\mathrm{P}_{240} \mathrm{Si}_{410}$ & 5.1 & 122 & 1.9 & 0.9 & 0.2 & 3.0 & 6.1 & 6.0 & 50.9 & 76.0 & 6.45 \\
\hline $\mathrm{P}_{410} \mathrm{Si}_{0}$ & 5.2 & 112 & 1.8 & 1.1 & 0.2 & 2.9 & 6.1 & 6.0 & 52.1 & 113.4 & 3.89 \\
\hline $\mathrm{P}_{410} \mathrm{Si}_{240}$ & 5.2 & 111 & 1.6 & 1.2 & 0.2 & 3.0 & 6.2 & 5.0 & 51.2 & 113.7 & 6.84 \\
\hline $\mathrm{P}_{410} \mathrm{Si}_{410}$ & 5.2 & 114 & 1.8 & 1.2 & 0.1 & 3.2 & 6.5 & 3.0 & 50.7 & 124.4 & 5.82 \\
\hline
\end{tabular}

Note. ${ }^{1}$ The rates of $\mathrm{P}$ and $\mathrm{Si}$ are in $\mathrm{mg} \mathrm{dm}{ }^{-3}$. CEC: Cation Exchange Capacity; total acidity pH $7.0\left(\mathrm{H}++\mathrm{Al}^{3+}\right)$; Exchangeable $\left(\mathrm{KCl} 1 \mathrm{~mol} \mathrm{~L}^{-1}\right) \mathrm{Ca}^{2+}, \mathrm{Mg}^{2+}$ and $\mathrm{Al}^{3+}$; $\mathrm{BS}$ : Base Saturation $=(\Sigma$ cations $/ \mathrm{CEC}) \times 100$; Si: silicon.

\subsection{Statistical Analysis}

The variables evaluated in the experiment were submitted to the analysis of variance (ANOVA) by the $F$-test (P $\leq 0.01)$ using the SISVAR statistical analyses software. In the case of significant $(\mathrm{P} \leq 0.01)$ difference in Si and $\mathrm{P}$ fertilizer rates, it was adjusted polynomial equation. Simple Person's correlations were applied between P forms, soil organic and inorganic P fractions with APDM, DMG, and P-APDM.

\section{Results and Discussion}

\subsection{Soil Inorganic Phosphorus (Pi) Fractions}

Significant interactions $(\mathrm{P}<0.01)$ were observed among the three factors in study for inorganic $\mathrm{P}$ in soil. Phosphorus fertilizer increased $\mathrm{P}$ content extracted by anionic exchange resin (Pi-resin), $\mathrm{NaHCO}_{3}\left(\mathrm{Pi}-\mathrm{NaHCO}_{3}\right)$ and $\mathrm{NaOH} 0.1$ (Pi_NaOH 0.1) (Table 3), which showed higher accumulation of Pi in fraction Pi_NaOH 0.1, indicating the excess of P-fertilizer can be accumulated in this fraction. These results confirm that Fe and $\mathrm{Al}$ oxides as goethite and gibbsite, and kaolinite promote higher bind capacity with $\mathrm{P}$, than this fraction acts as sink of Pi applied.

Bean cropping decreased the labile fractions (P-resin and $\mathrm{Pi}-\mathrm{NaHCO}_{3}$ ) in the most treatments assessed (Table 3), confirmed the lability of these fractions (Hedley et al., 1982). As reported by Lilienfein et al. (2000), the influence of crop cultivation is more affected in higher available Pi fractions. 
The Pi-NaOH 0.1 fraction increased after cultivating bean, indicating that this fraction does not contribute for bean uptakes and nutrition (Table 3), which can be considered low available to plants and its availability depends on soil chemical properties. The Pi-NaOH 0.5 fraction was the majority buffering of the labile fractions, and lower clay content explain the generalized reduction of $\mathrm{Pi}-\mathrm{NaOH} 0.5$ fraction, which is the most labile fraction observed. As observed by Santos et al. (2008) and Alovisi et al. (2016), the lower labile fraction participated in P supply for plants, proved by its decreasing in total P through time of P-fertilizer.

Silic (Si) fertilizer promoted higher $\mathrm{P}$ availability for plant uptakes under lower P-fertilizer rates, consequently decreased $\mathrm{Pi}-\mathrm{NaOH} 0.5$ fraction (Table 3). The increment in $\mathrm{P}$ availability due to Si-fertilizer resulted in a positive correlation between $\mathrm{Pi}-\mathrm{NaOH} 0.5$ fractions with dry matter of area part (DMAP), grain dry matter (GDM) and $\mathrm{P}$ accumulate in DMAP (P-DMAP) (Table 4). Possibly the mechanism of silicate in improving $\mathrm{P}$ availability can be associated with its capacity of Pi desorption in solid soil surface (Prado \& Fernandes, 2001). The Si-fertilizer may be increased the availability of $\mathrm{P}$ due to lower linked energy of phosphate with inorganic colloids, resulting in decreasing the $\mathrm{P}-\mathrm{NaOH} 0.5$ fraction (Table 3). As reported by Lopes (1984), the efficiency of $\mathrm{Si}$ in increasing $\mathrm{P}$ availability in soil is associated with blocking or saturation of adsorption sites by silicate anion.

Table 3. Soil inorganic $\mathrm{P}$ fractions after common bean cultivated

\begin{tabular}{|c|c|c|c|c|c|}
\hline & \multicolumn{5}{|c|}{ Inorganic $\mathrm{P}$ fractions $\left(\mathrm{mg} \mathrm{dm}^{-3}\right)$} \\
\hline & Resin-Pi & $\mathrm{NaHCO}_{3}-\mathrm{Pi}$ & $\mathrm{NaOH} 0.1 M-\mathrm{Pi}$ & $\mathrm{NaOH} 0.5 M-\mathrm{Pi}$ & HCl-Pi \\
\hline $\mathrm{P}_{0} \mathrm{Si}_{0}$ & $5.9(-8 \%)$ & $4.1(-49 \%)$ & $23.6(+25 \%)$ & $2.1(-2 \%)$ & $4.4(+78 \%)$ \\
\hline $\mathrm{P}_{0} \mathrm{Si}_{240}$ & $6.5(-14 \%)$ & $4.1(-54 \%)$ & $24.4(+38 \%)$ & $2.0(-51 \%)$ & $3.1(+67 \%)$ \\
\hline $\mathrm{P}_{0} \mathrm{Si}_{410}$ & $5.8(-2 \%)$ & $3.8(-50 \%)$ & $26.7(+55 \%)$ & $2.3(-45 \%)$ & $3.1(+59 \%)$ \\
\hline $\mathrm{P}_{80} \mathrm{Si}_{0}$ & $12.5(-2 \%)$ & $15.2(+0.4 \%)$ & $33.1(+37 \%)$ & $2.2(-26 \%)$ & $3.8(+60 \%)$ \\
\hline $\mathrm{P}_{80} \mathrm{Si}_{240}$ & $12.5(-29 \%)$ & $15.8(-9 \%)$ & $29.9(+29 \%)$ & $1.6(-72 \%)$ & $3.2(+49 \%)$ \\
\hline $\mathrm{P}_{80} \mathrm{Si}_{410}$ & $12.9(-22 \%)$ & $15.1(-22 \%)$ & $31.8(+33 \%)$ & $4.4(-63 \%)$ & $2.5(+55 \%)$ \\
\hline $\mathrm{P}_{240} \mathrm{Si}_{0}$ & $36.4(-28 \%)$ & $36.7(-12 \%)$ & $58.2(+15 \%)$ & $2.8(-11 \%)$ & $2.5(+18 \%)$ \\
\hline $\mathrm{P}_{240} \mathrm{Si}_{240}$ & $35.6(-26 \%)$ & $36.7(-2 \%)$ & $57.2(+23 \%)$ & $3.2(-2 \%)$ & $2.8(+25 \%)$ \\
\hline $\mathrm{P}_{240} \mathrm{Si}_{410}$ & $35.2(-33 \%)$ & $38.1(-3 \%)$ & $60.8(+26 \%)$ & $5.4(-34 \%)$ & $2.9(+5 \%)$ \\
\hline $\mathrm{P}_{410} \mathrm{Si}_{0}$ & $59.6(-28 \%)$ & $68.3(+22 \%)$ & $94.8(+37 \%)$ & $5.6(-64 \%)$ & $3.2(+21 \%)$ \\
\hline $\mathrm{P}_{410} \mathrm{Si}_{240}$ & $56.2(-25 \%)$ & $57.9(-5 \%)$ & $76.9(+7 \%)$ & $4.1(-44 \%)$ & $3.9(+45 \%)$ \\
\hline $\mathrm{P}_{410} \mathrm{Si}_{410}$ & $62.1(-29 \%)$ & $56.8(-19 \%)$ & $74.5(-5 \%)$ & $3.3(-5 \%)$ & $3.3(+20 \%)$ \\
\hline $\mathrm{CV}(\%)$ & 7.67 & 6.53 & 7.14 & 4.06 & 14.85 \\
\hline Soil form native vegetation & 5.22 & 5.33 & 15.64 & 2.88 & 1.41 \\
\hline
\end{tabular}

Note. ${ }^{1}$ The rates of $\mathrm{Si}$ and P-fertiliser applications are in $\mathrm{mg} \mathrm{\textrm {dm } ^ { - 3 }}$. Values between parentheses indicate percentage of decreasing (-) or increasing $(+)$ in the $\mathrm{P}$ fractions after the common bean cultivation.

Small amount of P-fertilizer was extracted in $\mathrm{HCl}(\mathrm{P}-\mathrm{HCl})$ fraction (Table 3), indicating lower quantity of P-fertilizer accumulated in this fraction. Due to soil acidity showed in this soil, resulting in lower content of $\mathrm{P}-\mathrm{HCl}$ fraction which is associated with lower Ca content and P-Ca (Walker \& Syers, 1976). The P-Ca turned available to plants uptakes if soil pH decreases, or decreasing of $\mathrm{P}$ or $\mathrm{Ca}$ in soil solution (Smiley, 1974). However, increasing of $\mathrm{P}-\mathrm{HCl}$ content was observed after bean cultivation, indicating that one part of P-fertilizer accumulated which suggested a new formation of Ca phosphate secondary resulted of in situ formation of Ca and $\mathrm{P}$ available, as well as Tiecher, Rheinheimer, and Calegari (2012). On the other hand, when Si-fertilizer was applied without P-fertilizer, the increment in $\mathrm{P}-\mathrm{HCl}$ was observed (Table 3). Possibly the application of Si-fertilizer decreased $\mathrm{P}$ uptake and controlled the mineralization of $\mathrm{P}-\mathrm{HCl}$ through the decreasing of Ca activity.

P-fertilizer rates increased $\mathrm{Pi}$ availability in higher labile fraction (P-resin and $\mathrm{Pi}-\mathrm{NaHCO}_{3}$ ) and moderated labile fraction ( $\mathrm{Pi}-\mathrm{NaOH}$ 0.1) (Figure 1), which is due to a process of $\mathrm{P}$ saturation sites (Conte, Anghinoni, \& Rheinheimer, 2003). The predominant sand fraction resulted in higher availability of Pi fractions in labile fraction due to low adsorption of $\mathrm{P}$. The increasing in Si-fertilizer rates resulted in higher Pi fractions in P-resin and $\mathrm{Pi}-\mathrm{NaHCO}_{3}$ before bean cultivation (Figure 1). Si-fertilizer application can increase the availability of $\mathrm{P}$ due to decrease the bound link energy of phosphate with inorganic colloids.

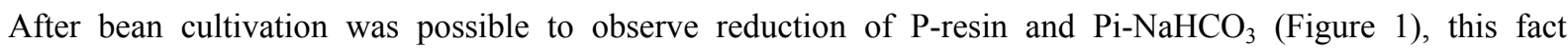
reinforces the higher availability of Pi uptake by bean plants with application of Si-fertilizer in soil, which was more evident with higher increment of Pi (Table 3). As reported by Lopes (1984), the efficiency of Si in 
increasing Pi availability of soil is not into the anions exchange capacity by phosphate in soil, but by saturation or blocking of adsorption sites of $\mathrm{P}$ by silicates anions.

\subsection{Soil Organic Phosphorus (Po) Fractions}

The interaction effects $(\mathrm{p}<0.01)$ were observed among three factors in study (bean cultivation, P-fertilizer and Si-fertilizer rates). The Po-NaOH 0.1 and $\mathrm{Po}-\mathrm{NaOH} 0.5$ fractions was predominant in Po extracted (Table 4), as well as observed by Cassagne and Remaury (2000).

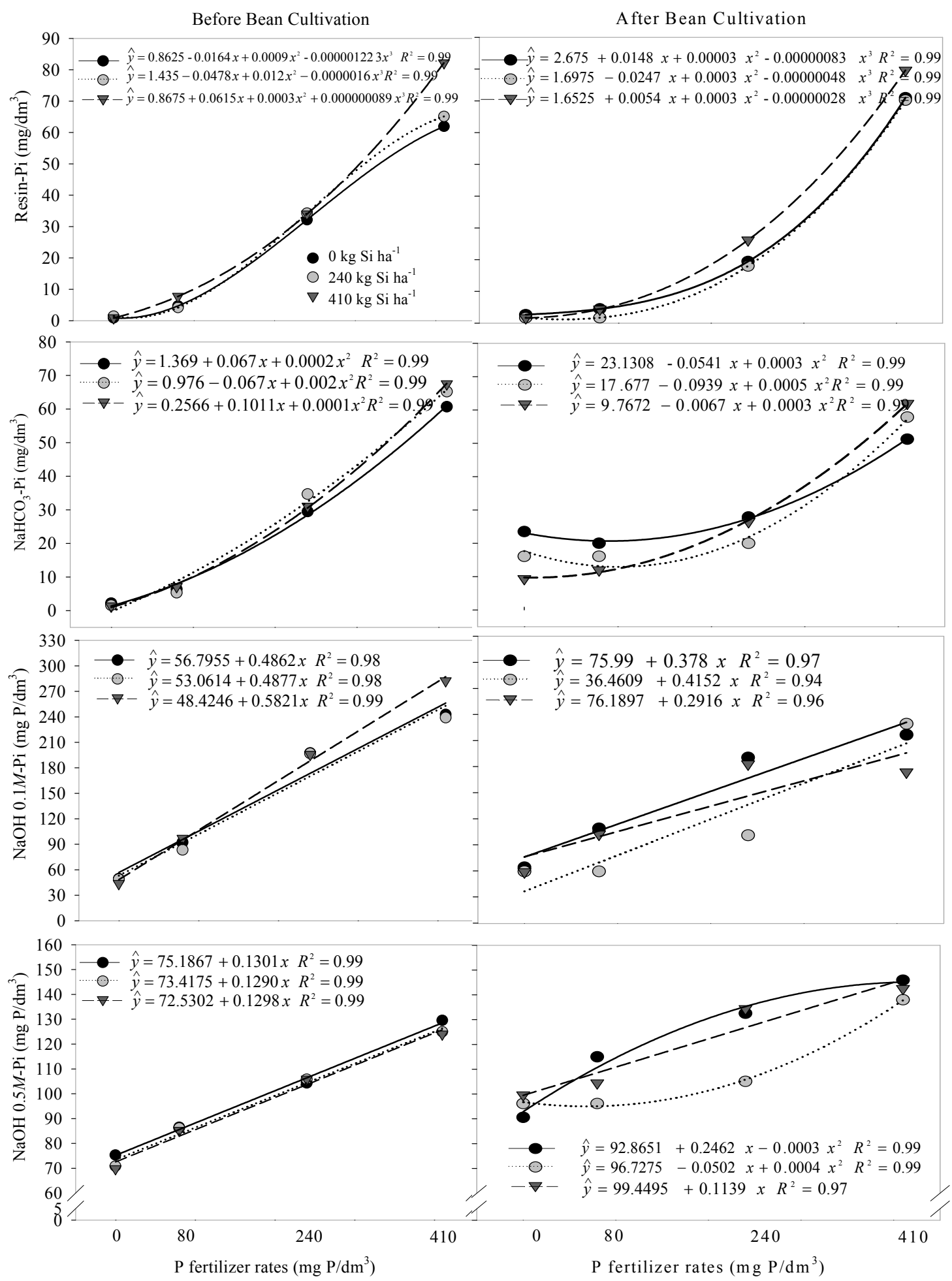

Figure 1. Soil inorganic $\mathrm{P}$ fractions affected by $\mathrm{P}$ and $\mathrm{Si}$ fertilizer rates under common bean cultivation 
Table 4. Soil organic $\mathrm{P}$ fractions after common bean cultivated

\begin{tabular}{|c|c|c|c|}
\hline \multirow{2}{*}{ Treatments $^{1}$} & \multicolumn{3}{|c|}{ Po fractions } \\
\hline & $\mathrm{NaHCO}_{3}-\mathrm{Po}$ & $\mathrm{NaOH} 0.1 M-\mathrm{P}_{\mathrm{o}}$ & $\mathrm{NaOH} 0.5 M-\mathrm{P}_{\mathrm{o}}$ \\
\hline & ------------- & $\mathrm{mg} \mathrm{dm}^{-3}$ & ----------------- \\
\hline $\mathrm{P}_{0} \mathrm{Si}_{0}$ & $21.8(-73 \%)$ & $51.2(-0.2 \%)$ & $61.6(+56 \%)$ \\
\hline $\mathrm{P}_{0} \mathrm{Si}_{240}$ & $19.0(-75 \%)$ & $33.0(-38 \%)$ & $27.7(-35 \%)$ \\
\hline $\mathrm{P}_{0} \mathrm{Si}_{410}$ & $19.4(-77 \%)$ & $45.1(-5 \%)$ & $27.5(-51 \%)$ \\
\hline $\mathrm{P}_{80} \mathrm{Si}_{0}$ & $19.0(-71 \%)$ & $50.9(+5 \%)$ & $51.0(+22 \%)$ \\
\hline $\mathrm{P}_{80} \mathrm{Si}_{240}$ & $18.7(-70 \%)$ & $45.8(+4 \%)$ & $26.72(+41 \%)$ \\
\hline $\mathrm{P}_{80} \mathrm{Si}_{410}$ & $25.7(-59 \%)$ & $46.1(-27 \%)$ & $17.9(-61 \%)$ \\
\hline $\mathrm{P}_{240} \mathrm{Si}_{0}$ & $26.3(-60 \%)$ & $23.4(-38 \%)$ & $30.4(-32 \%)$ \\
\hline $\mathrm{P}_{240} \mathrm{Si}_{240}$ & $25.7(-67 \%)$ & $27.1(-35 \%)$ & $28.2(+33 \%)$ \\
\hline $\mathrm{P}_{240} \mathrm{Si}_{410}$ & $23.5(-72 \%)$ & $32.6(-4 \%)$ & $31.1(-37 \%)$ \\
\hline $\mathrm{P}_{410} \mathrm{Si}_{0}$ & $30.5(-56 \%)$ & $33.1(+50 \%)$ & $37.1(+33 \%)$ \\
\hline $\mathrm{P}_{410} \mathrm{Si}_{240}$ & $21.8(-52 \%)$ & $34.9(+24 \%)$ & $47.9(+48 \%)$ \\
\hline $\mathrm{P}_{410} \mathrm{Si}_{410}$ & $27.4(-57 \%)$ & $33.9(+13 \%)$ & $39.9(+35 \%)$ \\
\hline C.V. $(\%)$ & 9.00 & 10.34 & 18.24 \\
\hline Soil form native vegetation & 29.54 & 59.85 & 1.95 \\
\hline
\end{tabular}

Note. ${ }^{1}$ The rates of $\mathrm{Si}$ and P-fertilizer applications are in $\mathrm{mg} \mathrm{dm}^{-3}$. Values between parentheses indicate percentage of decreasing (-) or increasing $(+)$ in the $\mathrm{P}$ fractions after the common bean cultivation.

Before bean cultivated, was observed increase in Po-NaOH 0.5 fraction and and decreasing in Po-bicarbonate with the increase of P-fertilizer rates in soil (Table 4 and Figure 2). The reduction is due to the higher mineralization of Po promoved by phosphate addiction and uptake of P by plants (Tokura et al., 2011). The Po-NaHCO ${ }_{3}$ fraction is related with organic compounds with faster decomposition, which sustains and is regulated by soil microbial biomass, once can be quickly mineralized (Gabitoni et al., 2008a, 2008b). As reported by Seybold et al. (1999), the transformation of Pi to Po in sand soils in relation to clay soil is easier to occur, due to lower amount of adsorption site in this soil, resulting in higher resilience of sand soil than clay soil in relation to Pi for Po transformation, as observed into the results in this research higher Pi fractions in detriment of Po fractions (Tables 3 and 4).

As reported by Kämpf and Curi (2000), the organic compounds showed an effect in inhibition in the process of $\mathrm{Fe}$ and $\mathrm{Al}$ oxides crystallization, which favorates the micro-crystallization of higher specific surface. As reported by Tokura et al. (2002), decreasing $\mathrm{P}$ desorption into mineral phase with increasing weathering is compensated by partitioin increasing of organic phase in $\mathrm{P}$ supply for plants. Thus, the organic $\mathrm{P}$ fraction can have relevant partition as nutrients sources by plants throughout releasing $\mathrm{P}$ by organic matter decomposition and mineralization (Novais \& Smyth, 1999; Cunha, Gama-Rodrigues, Costa, \& Velloso, 2007). Although, the precipitation reaction and adsorption of $\mathrm{P}$, that regulate the retentioin and the $\mathrm{P}$ release in soil, generally act with great intensity and fasterness, the permanent mineralization of organic compounds of these nutrients contribute to maintain in short and long time the levels of labile $P$ forms in soil, available for plants (Novais et al., 2007).

The significant correlation of Po-NaOH 0.5 with the variables DMAP, DMG and P-DMAP (Table 5), indicate that this Po fraction buffer the labile P fraction, which resulted in decreasing of $\mathrm{Po}-\mathrm{NaOH} 0.5$ after bean cultivation (Figure 2). As reported by Salcedo (2006), cropping increases soil microbial activity, resulting in higher mineralization of soil organic matter. However, higher amount of Po-NaOH 0.5 was observed in soil cropped with bean in relation to native vegetation (Table 5). These results reinforce the idea of Po accumulation, which can be an important $\mathrm{P}$ source for plants, although it is not quantified by usual method available for $\mathrm{P}$.

\subsection{Forms of P in Soil}

Silicon fertilizer as orthosilicic acid $\left(\mathrm{H}_{4} \mathrm{SiO}_{4}\right)$ source together with P-fertilizer didn't contribute to decrease P adsorption, which supports that silicon has lower affinity with $\mathrm{P}$ adsorption sites. The form of labile $\mathrm{P}$ and moderately labile were predominant (Figure 3), what is in accordance with the fact of magnitude of adsorption of $\mathrm{P}$ be dependable of quantity of constituents with capacity of adsorbed molecules (Bahia Filho, Braga, Resende, \& Ribeiro, 1983). The $\mathrm{P}$ forms in soil alterated after bean cultivation, resulting in decreasing $\mathrm{P}$ after the cultivation in higher amount in labile forms, followed by moderately labile and stable P forms (Table 6). This decreasing in $\mathrm{P}$ form indicated that these $\mathrm{P}$ forms contribute to bean nutrition, even the stable fraction. The confirmation of this contribution is based on positive and significant correlation of $\mathrm{Pi}-\mathrm{NaOH} 0.1, \mathrm{Pi}-\mathrm{NaOH}$, 
Po-NaOH 0.5 and P-HCl with DMAP, DMG and P-DMAP (Table5). In condition of sand soil, it is possible to infer that moderately and stable $\mathrm{P}$ fraction is dynamic and contribute to plant nutrition.

There was increment in stable $\mathrm{P}$ fraction after bean cultivation which indicates that this $\mathrm{P}$ form doesn't contributes to bean nutrition. The stable $\mathrm{P}$ forms showed negative correlation with the DMAP, DMG and P-DMAP (Table 5). The behave of P-fertilizer showed that the $\mathrm{P}$ availability turn to moderately and stable $\mathrm{P}$ fractions, due to surface reaction of clay mineral and $\mathrm{Fe}$ and $\mathrm{Al}$ oxides, resulting in inner complex sphere (Novais \& Smyth, 1999).

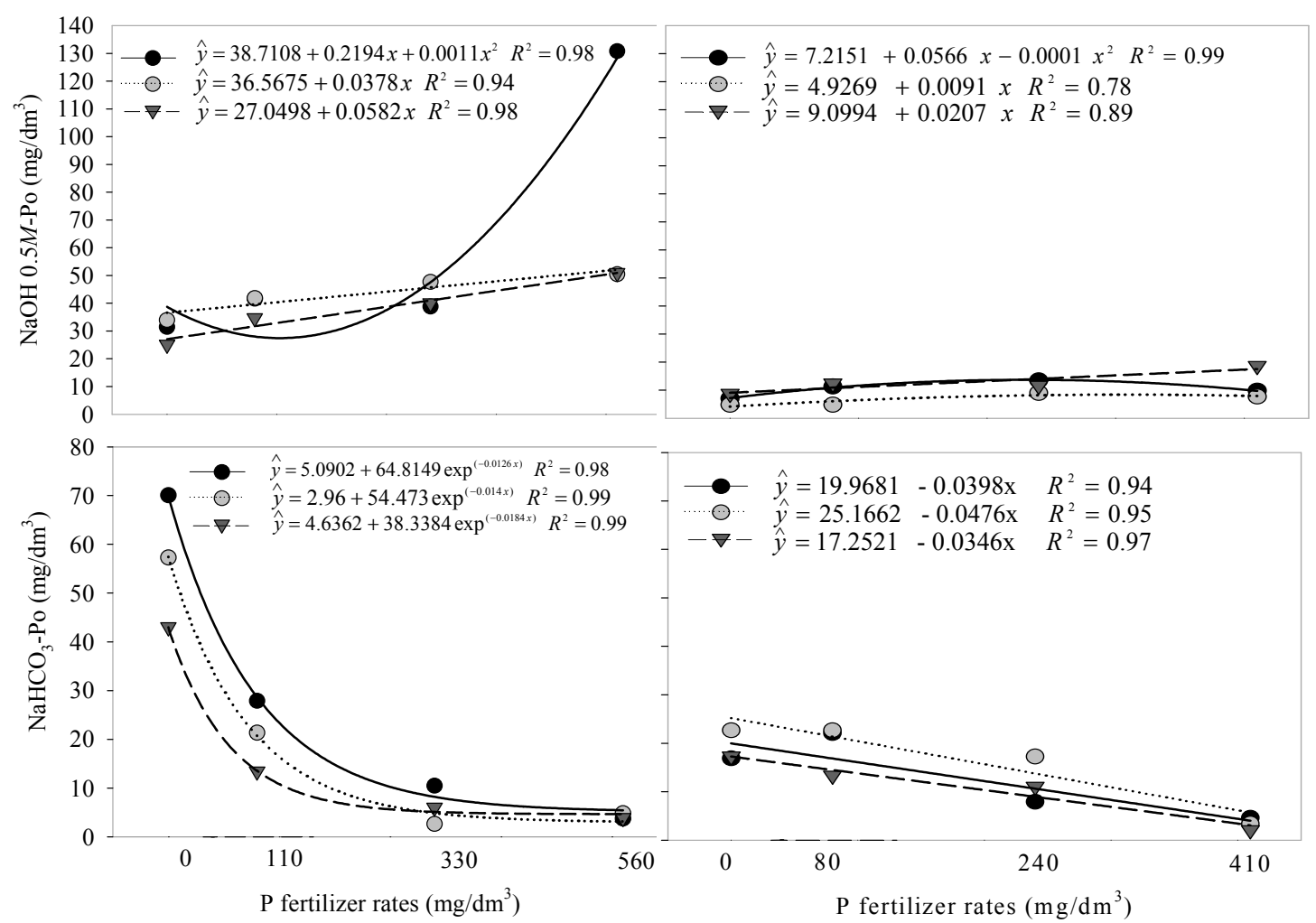

Figure 2. Soil organic $\mathrm{P}$ fractions affected by $\mathrm{P}$ and $\mathrm{Si}$ fertilizer under common bean cultivation

Table 5. Person's correlations between P fractions and forms with the dry matter aerial part (DMAP), grain dry matter (GDM), P accumulate in DMAP (P-DMAP)

\begin{tabular}{llll}
\hline $\mathrm{P}$ fractions and forms & DMAP & GDM & P-DMAP \\
\hline Resin-Pi & $0.75^{* *}$ & $0.76^{* *}$ & $0.87^{* *}$ \\
$\mathrm{NaHCO}_{3}-\mathrm{Pi}$ & $0.75^{* *}$ & $0.76^{* *}$ & $0.86^{* *}$ \\
$\mathrm{NaHCO}_{3}-\mathrm{Po}$ & $-0.84^{* *}$ & $-0.84^{* *}$ & $-0.91^{* *}$ \\
$\mathrm{NaOH} 0.1 \mathrm{M}-\mathrm{Pi}$ & $0.94^{* *}$ & $0.94^{* *}$ & $0.88^{* *}$ \\
$\mathrm{NaOH} 0.1 \mathrm{M}-\mathrm{Po}$ & $0.00 \mathrm{~ns}$ & $0.00 \mathrm{~ns}$ & $0.25 \mathrm{~ns}$ \\
$\mathrm{NaOH} 0.5 \mathrm{M}$-Pi & $0.91^{* *}$ & $0.94^{* *}$ & $0.88^{* *}$ \\
$\mathrm{NaOH} \mathrm{0.5} \mathrm{M-Po}$ & $0.48^{* *}$ & $0.53^{* *}$ & $0.45^{* *}$ \\
$\mathrm{HCl}-\mathrm{Pi}$ & $0.61^{* *}$ & $0.67^{* *}$ & $0.69^{* *}$ \\
$\mathrm{Residual}-\mathrm{Pi}$ & $-0.39^{*}$ & $-0.43^{* *}$ & $-0.50^{* *}$ \\
Labile-P & $0.74^{* *}$ & $0.73^{* *}$ & $0.85^{* *}$ \\
Moderately labile-P & $0.91^{* *}$ & $0.90^{* *}$ & $0.93^{* *}$ \\
Stable-P & $-0.37^{3}$ & $-0.34^{*}$ & $-0.34^{*}$ \\
\hline
\end{tabular}

Note. ${ }^{* *}$ significant at $1 \%$ of probability. ${ }^{*}$ significant at $5 \%$ of probability. NS no-significant. ${ }^{1}$ Labile $\mathrm{P}$ forms (resin-Pi, $\mathrm{NaHCO}_{3}-\mathrm{Po}$, and $\left.\mathrm{NaHCO}_{3}-\mathrm{Pi}\right),{ }^{2}$ moderately labile $(\mathrm{NaOH} 0.1 M$-Po, NaOH $0.1 M-\mathrm{Pi}, \mathrm{NaOH} 0.5$ $M-\mathrm{Po}$, and $\mathrm{NaOH} 0.5 \mathrm{M}-\mathrm{Pi}$ ), and ${ }^{3}$ stable $\mathrm{P}$ fractions ( $\mathrm{HCl}-\mathrm{Pi}$, and residual-Pi). 
Table 6. Soil phosphorus forms after common bean cultivated

\begin{tabular}{|c|c|c|c|}
\hline \multirow{2}{*}{ Treatments $^{1}$} & \multicolumn{3}{|c|}{ P forms } \\
\hline & Labile $\mathrm{P}^{2}$ & Moderately labile $\mathrm{P}^{3}$ & Stable $\mathrm{P}^{4}$ \\
\hline & \multicolumn{3}{|c|}{ 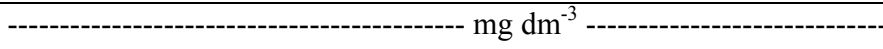 } \\
\hline $\mathrm{P}_{0} \mathrm{Si}_{0}$ & $31.9(-67 \%)$ & $138.4(+29 \%)$ & $20.3(+0.5 \%)$ \\
\hline $\mathrm{P}_{0} \mathrm{Si}_{240}$ & $29.2(-68 \%)$ & $87.0(-22 \%)$ & $22.6(+41 \%)$ \\
\hline $\mathrm{P}_{0} \mathrm{Si}_{410}$ & $29.1(-71 \%)$ & $101.6(-13 \%)$ & $24.2(+28 \%)$ \\
\hline $\mathrm{P}_{80} \mathrm{Si}_{0}$ & $46.7(-52 \%)$ & $137.1(+19 \%)$ & $23.1(+17 \%)$ \\
\hline $\mathrm{P}_{80} \mathrm{Si}_{240}$ & $46.9(-52 \%)$ & $104.0(+19 \%)$ & $16.9(-19 \%)$ \\
\hline $\mathrm{P}_{80} \mathrm{Si}_{410}$ & $53.7(-37 \%)$ & $100.3(-24 \%)$ & $13.4(-38 \%)$ \\
\hline $\mathrm{P}_{240} \mathrm{Si}_{0}$ & $99.5(-37 \%)$ & $114.7(-15 \%)$ & $22.2(+13 \%)$ \\
\hline $\mathrm{P}_{240} \mathrm{Si}_{240}$ & $98.0(-40 \%)$ & $115.7(+7 \%)$ & $14.1(-19 \%)$ \\
\hline $\mathrm{P}_{240} \mathrm{Si}_{410}$ & $96.7(-45 \%)$ & $130.0(-3 \%)$ & $17.8(-27 \%)$ \\
\hline $\mathrm{P}_{410} \mathrm{Si}_{0}$ & $158.4(-23 \%)$ & $170.7(+22 \%)$ & $22.5(+28 \%)$ \\
\hline $\mathrm{P}_{410} \mathrm{Si}_{240}$ & $135.8(-25 \%)$ & $163.9(+26 \%)$ & $20.1(+31 \%)$ \\
\hline $\mathrm{P}_{410} \mathrm{Si}_{410}$ & $146.3(-34 \%)$ & $151.5(+10 \%)$ & $15.9(-30 \%)$ \\
\hline $\mathrm{CV}(\%)$ & 5.31 & 3.82 & 3.46 \\
\hline Soil from native vegetation & 30.48 & 91.54 & 22.22 \\
\hline
\end{tabular}
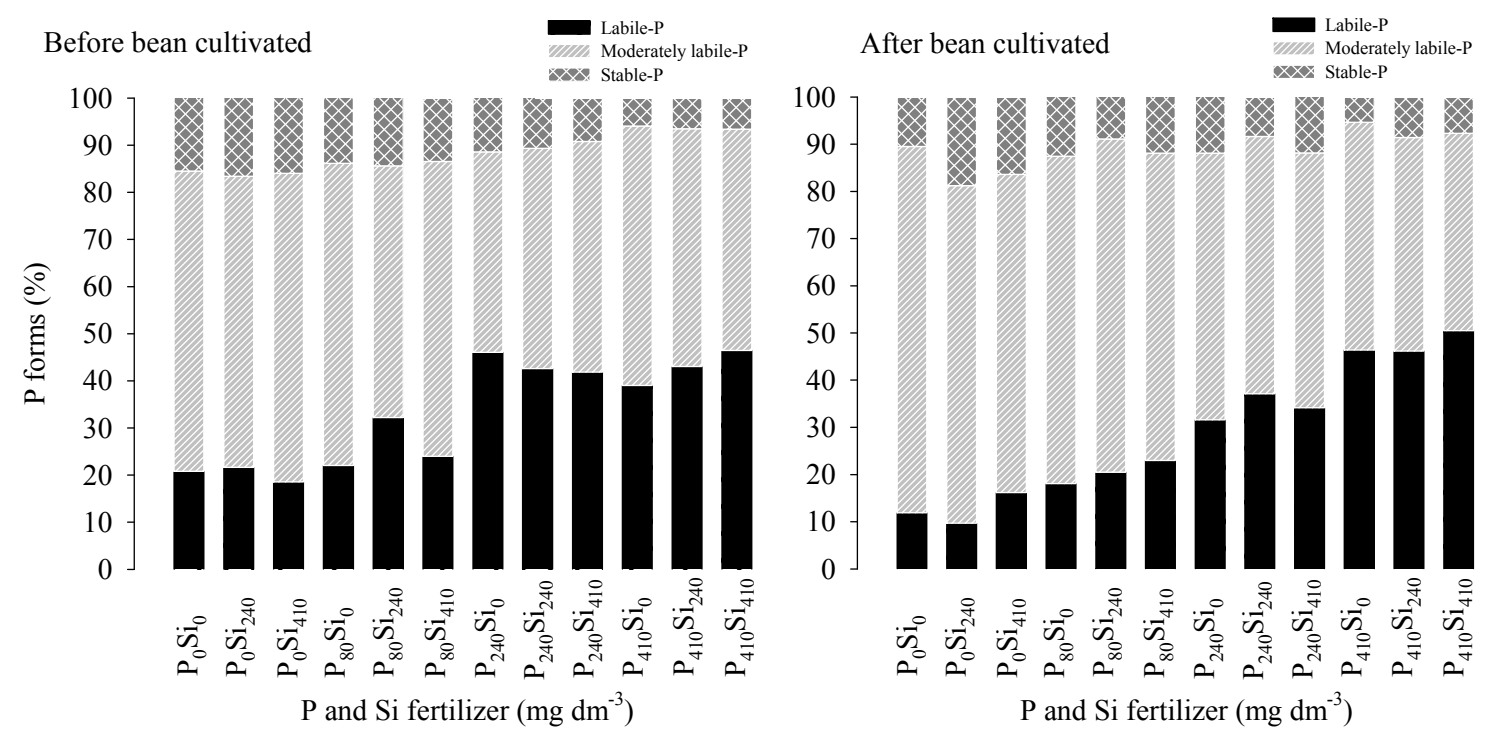

Figure 3. Effects of Si and P-fertilizer rates on soil $\mathrm{P}$ fractions before and after common bean cultivated. ${ }^{1}$ Labile P forms (resin-Pi, $\mathrm{NaHCO}_{3}-\mathrm{Po}$, and $\left.\mathrm{NaHCO}_{3}-\mathrm{Pi}\right),{ }^{2}$ moderately labile $(\mathrm{NaOH} 0.1 M-\mathrm{Po}, \mathrm{NaOH} 0.1 M$ - $\mathrm{Pi}, \mathrm{NaOH}$ $0.5 M-\mathrm{Po}$, and $\mathrm{NaOH} 0.5 \mathrm{M}-\mathrm{Pi}$ ), and ${ }^{3}$ stable $\mathrm{P}$ fractions ( $\mathrm{HCl}-\mathrm{Pi}$, and residual-Pi)

\section{Conclusion}

Phosphorus fractions in soil are little affected by Si-fertilizer rates. P uptakes by bean plants are correlated with the labile and moderately labile fractions.

P-fertilizer rates increment majority the stable $\mathrm{P}$ fraction in soil and in lower proportion the labile and moderately labile $\mathrm{P}$ fractions in soil. $\mathrm{Po}-\mathrm{NaHCO}_{3}$ is the only that contribute to bean plant nutrition.

\section{References}

Albuquerque, J. A., Almeida, J. A., Gatiboni, L. C., \& Eltz, F. L. F. (2011). Atividades agrícolas de produção em solos frágeis no sul do Brasil. In O. Klauberg Filho, A. L. Mafra, \& L. C. Gatiboni (Eds.), Tópicos em Ciência do Solo (pp. 368-403). Viçosa, MG: Sociedade Brasileira de Ciência do Solo. 
Alovisi, A. M. T., Furtini Neto, A. E., Serra, A. P., Alovisi, A. A., Tokura, L. K., Lourente, E. R. P., ... Fernandes, J. S. (2016). Phosphorus and silicon fertilizer rates effects on dynamics of soil phosphorus fractions in oxisol under comom bean cultivation. African Journal of Agricultural Research, 11(30), 2697-2702. https://doi.org/10.5897/AJAR2016.11304

Alvarez, V. H., Novais, R. F., Dias, L. E., \& Oliveira, J. A. (2000). Determinação de fósforo remanescente. Sociedade Brasileira de Ciência do Solo. Boletim Informativo, 25(1), 27-30.

Bahia Filho, A. F. C., Braga, J. M., Resende, M., \& Ribeiro, A. C. (1983). Relação entre adsorção de fósforo e componentes mineralógicos da fração argila de Latossolos do Planalto Central. Revista Brasileira de Ciência do Solo, 7(3), 221-226.

Braga, J. M., \& Defelipo, B. V. (1974). Determinação espectrofotométrica de fósforo em extratos de solos e plantas. Revista Ceres, 21, 73-85.

Brait, M. A. H. (2008). Interação silício e fósforo na adsorção desses elementos em diferentes solos de cerrado (Master's thesis, Universidade Federal de Goiás, Jataí, Goiás).

Cassagne, N., \& Remaury, M. (2000). Forms and profile distribution of soil phosphorus in alpine Inceptisols and Spodosols (Pyrenees, France). Geoderma, 95, 161-172. https://doi.org/10.1016/S0016-7061(99)00093-2

Claessen, M. E. C. (1997). Manual de Métodos de Análise de Solo (2nd ed.). Rio de Janeiro: EMBRAPA-CNPS.

Conte, E., Anghinoni, I., \& Rheinheimer, D. S. (2003). Frações de fósforo acumulada em latossolo argiloso pela aplicação de fosfato no sistema plantio direto. Revista Brasileira de Ciência do Solo, 27(5), 893-900. https://doi.org/10.1590/S0100-06832003000500014

Cunha, G. M., Gama-Rodrigues, A. C., Costa, G. S., \& Velloso, A. C. X. (2007). Organic phosphorus in diagnostic surface horizons of different Brazilian soil orders. Revista Brasileira de Ciência do Solo, 31, 667-671. https://doi.org/10.1590/S0100-06832007000400007

Day, P. R. (1965). Particle fractionation and particle-size analysis. In C. A. Black (Ed.), Methods of soil analysis (Vol. 1, pp. 545-556). Madison: American Society of Agronomy.

Fontes, M. P. F., Camargo, O. A., \& Sposito, G. (2001). Eletroquímica das partículas coloidais e sua relação com a mineralogia de solos altamente intemperizados. Scientia Agricola, 58(3), 627-646. https://doi.org/10.1590/ S0103-90162001000300029

Freire, J. C., Ribeiro, M. A. V., Bahia, V. G., Lopes, A. S., \& Aquino, L. H. (1980). Resposta do milho cultivado em casa de vegetação a níveis de água em solos da região de Lavras (MG). Revista Brasileira de Ciência do Solo, 4(1), 5-8.

Gatiboni, L. C., Brunetto, G., Kaminski, J., Rheinheimer, D. S., Ceretta, C. A., \& Basso, C. J. (2008a). Formas de fósforo no solo apóssucessivas adições de dejeto líquido de suínos em pastagem natural. Revista Brasileira de Ciência do Solo, 32(4), 1753-1761. https://doi.org/10.1590/S0100-06832008000400040

Gatiboni, L. C., Kaminski, J., Rheinheimer, D. S., \& Brunetto, G. (2008b). Fósforo da biomassa microbiana e atividade de fosfatases ácidas durante a diminuição do fósforo disponível no solo. Pesquisa Agropecuária Brasileira, 43(8), 1085-1091. https://doi.org/10.1590/S0100-204X2008000800019

Hedley, M. J., Stewart, J. W. B., \& Chauhan, B. S. (1982). Changes in inorganic soil phosphorus fractions induced by cultivation practices and laboratory incubations. Soil Science Society of America Journal, 46(4), 970-976. https://doi.org/10.2136/sssaj1982.03615995004600050017x

Kampf, N., \& Curi, N. (2000). Óxidos de ferro: Indicadores de ambientes pedogênicos e geoquímicos. In R. F. Novais, V. Alvarez, \& C. E. G. R. Schaefer (Eds.), Tópicos em Ciência do Solo. Viçosa, MG.

Lilienfein, J., Wilcke, W., Ayarza, M. A., Vilela, L., Lima, S. C., \& Zech, W. (2000). Chemical fractionation of phosphorus, sulphur, and molybdenum in Brazilian savannah Oxisols Ander different land use. Geoderma, 96(1/2), 31-46. https://doi.org/10.1016/S0016-7061(00)00002-1

Lopes, A. S. (1984). Solos sob Cerrado: Características, propriedades e manejo (2nd ed.). Piracicaba: Associação Brasileira para Pesquisa da Potassa e do Fosfato.

Malavolta, E., Vitti, G. C., \& Oliveira, A. S. (1997). Avaliação do estado nutricional das plantas: Princípios e aplicações (2nd ed.). Piracicaba: POTAFOS.

Mckeague, J. A., \& Cline, M. G. (1963). Silica in soils. II. The adsorption of monosilicic acid by soil and by other substances. Canadian Journal of soil Science, 43(1), 83-95. https://doi.org/10.4141/cjss63-011 
Mehra, O. P., \& Jackson, M. L. (1960). Iron oxide removal from soil and clays by a dithionite-citrate system buffered with sodium bicarbonate. Clays and Clay Minerals, 7(5), 317-327.

Menegale, M. L. C., Castro, G. S. A., \& Mancuso, M. A. C. (2015). Silício: interação com o sistema solo-planta. Journal of Agronomic Science, 4, 435-454.

Novais, R. F., \& Smyth, T. J. (1999). Fósforo em solo e planta em condições tropicais. Viçosa: Universidade Federal de Viçosa.

Novais, R. F., Alvarez, V. V. H., Barros, N. F., Fontes, R. L. F., Cantarutti, R. B., \& Neves, J. C. L. (2007). Fertilidade do solo. Sociedade Brasileira de Ciência do Solo, Viçosa.

Prado, R. M., \& Fernandes, F. M. (2001). Resposta da cana-de-açúcar à aplicação da escória de siderurgia como corretivo de acidez do solo. Revista Brasileira de Ciência do Solo, 25, 201-209. https://doi.org/10.1590/ S0100-06832001000100021

Raij, B. Van, \& Feitosa, C. T. (1980). Correlação entre o P extraído de solo por diversos extratores químicos extratores químicos e o absorvido pelo milho. Bragantia, 39(1), 51-57. https://doi.org/10.1590/S0006-870 51980000100007

Salcedo, I. H. (2006). Biogeoquímica do fósforo em solos da região semi-árida do NE do Brasil. Revista de Geografia, 23, 108-123.

Santos, H. G., Jacomine, P. K. T., Anjos, L. H. C., Oliveira, V. A., Lubreras, J. F., Coelho, M. R, ... Oliveira, J. B. (2013). Sistema Brasileiro de Classificação de Solos (3rd ed.). Brasília: EMBRAPA.

Santos, J. Z. L., Furtini Neto, A. E., Resende, A. V., Curi, N., Carneiro, L. F., \& Costa, S. E. V. G. A. (2008). Frações de fósforo em solo adubado com fosfatos em diferentes modos de aplicação e cultivado com milho. Revista Brasileira de Ciência do Solo, 32, 705-714. https://doi.org/10.1590/S0100-06832008000200025

Schwertman, U., Kodama, H., \& Fisher, W. R. (1986). Mutual Interaction between organics and iron oxides. In P. M. Huang, \& M. Schnitzer (Eds.), Interactions of Soil Minerals with Natural Organics and Microbes (pp. 223-250). SSSA, Madison.

Seybold, C. A., Herrick, J. E., \& Brejda, J. J. (1999). Soil resilience: A fundamental component of soil quality. Soil Science, 164(4), 224-234. https://doi.org/10.1097/00010694-199904000-00002

Smiley, R. W. (1974). Rhizosphere pH as influenced by plants, soils, and nitrogen fertilizers. Soil Science Society of America Journal, 38, 795-801. https://doi.org/10.2136/sssaj1974.03615995003800050030x

Soil Survey Staff. (2014). Keys to soil taxonomy (12nd ed). Washington, DC: USDA-Natural Resources Conservation Service.

Tiecher, T., Rheinheimer, D. S., \& Calegari, A. (2012). Soil organic phosphorus forms under different soil management systems and winter crops, in a long term experiment. Soil \& Tillage Research, 124, 57-67. https://doi.org/10.1016/j.still.2012.05.001

Tokura, A. M., Furtini Neto, A. E., Carneiro, L. F., Curi, N., Santos, J. Z. L., \& Alovisi, A. A. (2011). Dinâmica das formas de fósforo em solos de textura e mineralogia contrastantes cultivados com arroz. Acta Scientiarum-Agronomy, 33, 171-179. https://doi.org/10.4025/actasciagron.v33i1.1435

Tokura, A. M., Furtini Neto, A. E., Curi, N., Faquin, V., Kurihara, C. H., \& Alovisi, A. A. (2002). Formas de fósforo em solo sob plantio direto em razão da profundidade e tempo de cultivo. Pesquisa Agropecuária Brasileira, 37, 1467-1476. https://doi.org/10.1590/S0100-204X2002001000015

Walker, T., \& Syers, J. (1976). The fate of phosphorus during pedogenesis. Geoderma, 15, 1-19. https://doi.org/ 10.1016/0016-7061(76)90066-5

\section{Copyrights}

Copyright for this article is retained by the author (s), with first publication rights granted to the journal.

This is an open-access article distributed under the terms and conditions of the Creative Commons Attribution license (http://creativecommons.org/licenses/by/4.0/). 